\title{
MANAJEMEN KURIKULUM BERBASIS PENDIDIKAN ISLAM MASA PANDEMI COVID-19
}

\author{
Devi Vionitta Wibowo, ${ }^{1}$ Erni Munastiwi, ${ }^{2}$ Ahmad Sanusi ${ }^{3}$ \\ 1,2Universitas Islam Negeri Sunan Kalijaga Yogyakarta \\ ${ }^{1}$ Email: vionittadevi@gmail.com \\ 2Email: erni.munastiwi@uin-suka.ac.id \\ 3Email: 1920403001@uin-suka.ac.id
}

\begin{abstract}
Abstrak: Tujuan kepenulisan ini adalah untuk mengetahui manajemen kurikulum darurat berbasis pendidikan Islam di RA Masyithoh Rembang agar dapat mencapai tujuan pendidikan Islam yang efektif dan efisien selama pandemi Covid-19. Metode penelitian menggunakan metode kualitatif dengan investigasi serta interview kepada kepala sekolah, waka kurikulum, dan para guru wali kelas di RA Masyithoh Rembang. Hasil penelitian menyatakan bahwa adanya implementasi manajemen kurikulum darurat berbasis pendidikan Islam yang meliputi perencanaan, pengorganisasian, pelaksanaan, dan evaluasi agar dapat menciptakan pendidikan Islam yang berkarakter sesuai dengan tuntunan Al-Qur'an dan Hadist Nabi. Pihak lembaga membuat SOP terkait program kerja tambahan berupa bimbingan belajar, parenting, pengambilan media dan pelaporan hasil belajar anak selama pandemi yang dilaksanakan setiap seminggu sekali. Adanya peningkatan kinerja guru serta peningkatan kemandirian dan kedisiplinan dalam diri anak saat pengimplementasian kurikulum darurat berbasis pendidikan Islam di RA Masyithoh Rembang.
\end{abstract}

Kata Kunci: Manajemen, Kurikulum Darurat, Pendidikan Islam, Pandemi Covid-19.

Title: Islamic Education Curricullum Based on Covid-19 Pandemic

Abstract: The purpose of this article is to determine the management of an Islamic education-based emergency curriculum at $\mathrm{R} A$ Masyithoh to make effectively and efficiently for Islamic education during pandemic-19. The research method used qualitative methods with investigations and interviews. The results of the study indicate that there is an implementation of an Islamic education-based emergency curriculum management which includes planning, organizing, implementing, and evaluating in order to create an Islamic education with character in accordance with the guidance of the Al-Qur'an and the Prophet's Hadith. The institution makes SOP related to additional work programs in the form of study guidance, parenting, media collection and screening of children's learning outcomes which is carried out once a week. There is an increase in teacher performance and an increase in independence and discipline in children character when implementing Islamic education-based emergency curriculum at $\mathrm{R} A$ Masyithoh Rembang.

Keywords: Management, Emergency Curriculum, Islamic Education, Covid-19 Pandemic 


\section{PENDAHULUAN}

Kurikulum di masa pandemi Covid-19 telah disederhanakan sesuai dengan kebutuhan anak. Hal ini dikarenakan adanya sistem pembelajaran daring yang dilaksanakan di masa pandemi Covid-19. Guru melakukan pembelajaran dengan menggunakan sebuah teknologi sebagai media belajar anak. Hal ini sebagai bentuk upaya pemerintah dalam menanggulangi peningkatan penyebaran virus pada masyarakat setempat. ${ }^{1}$ Adanya sistem pembelajaran daring ini, banyak para guru, anak didik, maupun orangtua merasa kesulitan untuk melakukan pembelajaran. Terlebih para guru yang merasakan kesulitan dalam mengajarkan anak akan pendidikan Islam di masa pandemi. Adanya problematika ini, Kementerian Pendidikan dan Kebudayaan membuat suatu kurikulum darurat yang disederhanakan sesuai dengan kebutuhan anak yang diberi nama kurikulum darurat di masa pandemi. ${ }^{2}$

Adanya penjabaran diatas, dapat dijadikan acuan untuk pihak lembaga terkhusus pada satuan PAUD untuk mengembangkan kurikulum mereka sesuai dengan kebutuhan dan kondisi di saat pandemi. Kurikulum PAUD sangatlah dianjurkan untuk diterapkan dan dikembangkan dari usia 0-6 tahun agar dapat membantu tumbuh kembang anak secara optimal. ${ }^{3}$ Kurikulum yang telah disepakati bersama harus bersifat mempermudah bukan mempersulit jalannya proses pembelajaran saat pandemi. Adanya kondisi ini, maka perlu diterapkannya suatu manajemen pengembangan kurikulum yang dirancang dan dilaksanakan sebagai bantuan dan pondasi dasar untuk menjadikan kurikulum di saat pandemi menjadi efektif dan efisien sesuai dengan kebutuhan anak.

Manajemen kurikulum PAUD merupakan sebuah tindakan yang dilakukan oleh pihak lembaga dalam mengelola kurikulum sekolah menjadi produktif, demokratis, koperatif, dan mengarah kepada visi, misi serta tujuan pembelajaran. Pihak lembaga harus menjadikan kurikulum sekolah sebagai pedoman pembelajaran yang produktif dan demokratisasi dengan cara mengelolanya secara kebersamaan. Pihak lembaga juga memanajemen kurikulum sekolah berlandaskan atas visi, misi serta tujuan sekolah agar dapat terealisasikan dengan efektif dan efisien. ${ }^{4}$

Pada artikel kali ini akan membahas mengenai menejemen kurikulum darurat berbasis pendidikan Islam di masa Pandemi. Peneliti beragumen bahwa pendidikan Islam bagi anak

\footnotetext{
1 mam Subhi, "Urgensi Upaya Menjaga Mutu Pembelajaran Di Tengah Pndemi Covid 19,” Edification Jurnal: Pendidikan Agama Islam 3, no. 1 (2020): 36-56, https://doi.org/DOI: https://doi.org/10.37092/ej.v3i1.213.

2 Nyoman Ary Wahyudi, "Kemendikbud Terbitkan Kurikulum Darurat, Ini Alasannya," Bisnis.com, 2020, https://kabar24.bisnis.com/read/20200807/15/1276481/kemendikbud-terbitkan-kurikulum-daruratini-alasannya.

${ }^{3}$ Rahimah dkk Ahmad, Mushlih, Analisis Kebijakan PAUD: Mengungkap Isu-Isu Menarik Seputar AUD (Wonosobo: Penerbit Bangku Bumi, 2018). hlm. 207

4 Irjus Indrawan Hadion Wijoyo, "Model Pembelajaran Menyongsong New Era Normal Pada Lembaga Paud Di Riau," Jurnal Sekolah (JS) 4, no. 3 (2020).
} 
usia dini sangatlah dianjurkan untuk diterapkan di lembaga PAUD terkhusus lembaga Raudlatul Athfal. Studi Penelitian menyatakan bahwa para guru harus bisa mengembangkan pembelajaran berbasis pendidikan Islam melalui jarak jauh atau daring. Hal ini dikarenakan banyaknya problematika terkait kurangnya pemahaman anak terkait pendidikan Islam, seperti hafalan Al-Qur'an, pendidikan karakter, dan kegiatan pendidikan Islam lainnya 5. Adanya hal tersebut, pendidikan Islam sangatlah dianjurkan untuk diimplementasikan bagi pendidikan anak usia belia agar dimasukkan kedalam kurikulum darurat masa pandemi. Studi penelitian menyatakan bahwa para guru dan orangtua bekerjasama dalam membimbing anak untuk belajar dan membiasakan anak untuk berkarakter yang baik sesuai dengan tuntunan pendidikan Islam. 6 Adanya penelitian tersebut maka, artikel ini bertujuan untuk mengetahui implementasi terkait manejemen kurikulum darurat berbasis pendidikan Islam saat pandemi Covid-19 di Lembaga Raudlatul Athfal (RA). Peneliti berharap dapat menjadikan artikel ini menjadi penunjang keefektifan dan keefisiensi penelitian pendidikan Islam yang berfokus pada manajemen pengembangan kurikulum pada satuan pendidikan Islam Raudlatul Athfal. Kegunaan artikel ini adalah dapat dijadikan keilmuan bagi pendidik RA dalam memanajemen kurikulum darurat masa pandemi Covid-19.

\section{KAJIAN LITERATUR}

\section{Manajemen Kurikulum}

Manajemen kurikukulum merupakan kegiatan yang dilakukan oleh pihak lembaga dalam mengelola kurikulum pendidikan yang terdiri dari kegiatan perencanaan, pengorganisasian, pelaksanaan serta evaluasi agar dapat menciptakan kurikulum sekolah yang efektif dan efisien. ${ }^{7}$ Kurikulum diaplikasikan sebagai pedoman pembelajaran bagi anak yang berisikan beberapa dokumen pembelajaran, visi, misi, tujuan dan profil sekolah. ${ }^{8}$ Manajemen kurikulum harus berpedoman pada tujuan pendirian sekolah, dan merujuk kepada implementasi pembelajaran yang menarik sesuai dengan perkembangan anak. ${ }^{9}$ Adapun prinsip manajemen kurikulum adalah mengedepankan pada aspek pembelajaran yang

${ }^{5}$ Senata Adi Prasetia and Muhammad Fahmi, "Reorientasi, Peran Dan Tantangan Pendidikan Islamdi Tengah Pandemi," Jurnal Tarbawi STAI Al- Fitrah 9, no. 1 (2020): 21-35, https://doi.org/https://doi.org/10.36781/tarbawi.v9i1.3128.

${ }^{6}$ Lia Dwi Ayu Pagarwati and Arif Rohman, "Grandparenting Membentuk Karakter Anak Usia Dini Di Masa Pandemi Covid-19," Jurnal Obsesi: Journal of Early Childhood Education 5, no. 2 (2021): 1229-39, https://doi.org/10.31004/obsesi.v5i2.831.

7 Suhelayanti and Ridwan Aziz, Manajemen Pendidikan, ed. Toni Limbong, Pertama (Jakarta: Yayasan Kita Menulis, 2020). hlm. 20

8 Zainal Arifin, Konsep Dan Model Pengembang Kurikulum (Bandung: Remaja Rosda Karya, 2011). hlm. 34

9 Eca Gesang and dkk, Manajemen Pengembangan Pendidikan Anak Usia Dini (Yogyakarta: Hijaz Pustaka Mandiri, 2020). hlm. 59 
produktif. Adanya kerjasama tim pengembang kurikulum dalam menerapkan kurikulum agar menjadi efektif dan efisein 10

Adapun manfaat dari implementasi manajemen kurikulum adalah sebagai pengelolaan dalam merencanakan, melaksanakan, serta mengevaluasi jalannya proses pembelajaran yang dilakukan oleh pihak lembaga agar berjalan sesuai dengan harapan. ${ }^{11}$ Adapun fungsi manajemen kurikulum ini adalah sebagai bentuk kinerja pendidik dalam meningkatkan efektivitas dan efisiensi terhadap proses pembelajaran yang diterapkan oleh anak didik ${ }^{12}$

\section{Kurikulum Darurat Masa Pandemi}

Masa pandemi Covid-19 merupakan masa yang harus diperhatikan agar tidak tertular. Pandemi ini menjadi tantangan tersendiri bagi terlaksananya pendidikan yang ada di Indonesia. Banyak dampak yang didapat dari pandemi ini, terlebih bagi pendidikan yang ada di Indonesia. Dampak yang dirasakan adalah para tenaga pendidik merasa kesulitan dalam pembelajaran, terlebih pembelajaran diadakan dari jarak jauh, kurangnya kapasitas internet dan kuota, kurangnya implementasi pendidikan yang secara langsung. ${ }^{13}$ Adanya kondisi ini, maka Kementerian Pendidikan membuat sebuah kurikulum darurat untuk dijadikan pedoman pembelajaran yang baik dan terprogram bagi terselenggaranya pendidikan di Indonesia. Kurikulum ini telah disederhanakan sesuai dengan kebutuhan anak. Implementasiannya secara terprogram, terperinsi dan disederhanakan sesuai kompetensi dasar dan inti pada kurikulum sebelumnya. ${ }^{14}$

Penggunaan kurikulum darurat ini bertujuan sebagai pembantu pendidik dalam mengorganisis jalannya pendidikan selama masa pandemi. Hal ini tentunya berlandaskan atas kebutuhan anak dan sesuai dengan kondisi dan situasi anak di rumah. pengimplementasiannya tetap mengacu pada kurikulum nasional, hanya saja dikembangkan dan disederhanakan sehingga dapat diimplementasikan dengan sederhana dan mudah. Adapun evaluasinya berlandaskan atas evaluasi keseharian anak serta keberhasilan anak ketika mengikuti pembelajaran secara daring atau jarak jauh. ${ }^{15}$ Kurikulum darurat ini juga

10 Tim Dosen Adpen UPI, Manajemen Pendidikan (Bandung: Alfabeta, 2015). hlm.196

11 Rusman, Manajemen Kurikulum (Jakarta: PT Raja Grafindo Persada, 2009). hlm. 21

12 Baharuddin and Mohammad Makin, Manajemen Pendidikan Islam: Transformasi Menuju Sekolah/Madrasab Yang Unggul (Malang: UIN Maulana Malik Ibrahim Malang Press, 2010). hlm. 54

13 Arifah Prima Satrianingrum and Iis Prasetyo, "Persepsi Guru Dampak Pandemi Covid-19 Terhadap Pelaksanaan Pembelajaran Daring Di PAUD," Jurnal Obsesi : Journal of Early Childhood Education 5, no. 1 (2021): 633-40, https://doi.org/10.31004/obsesi.v5i1.574.

${ }^{14}$ Kemdikbud, "Kemendikbud Terbitkan Kurikulum Darurat Pada Satuan Pendidikan Dalam Kondisi Khusus," https://www.kemdikbud.go.id/,

2020,

https://www.kemdikbud.go.id/main/blog/2020/08/kemendikbud-terbitkan-kurikulum-darurat-pada-satuanpendidikan-dalam-kondisi-khusus.

15 Kemdikbud, "Kepmendikbud Nomor 719/P/2020 Tentang Pedoman Pelaksanaan Kurikulum Pada Satuan Pendidikan Dalam Kondisi Khusus," Www.Kemdikbud.Go.Id, no. 022651 (2020): 9, 
memiliki sisi fleksibilitas yang tinggi sebagai modal panduan pembelajaran jarak jauh bagi anak didik. Adapun tujuan penggunaanya adalah sebagai bahan untuk meningkatkan potensi, intelektual, karakter, spiritualitas, dan kesehatan jasmani anak didik. Maka dari hal tersebut, implementasi pembelajarannya dilakukan sesuai dengan kebutuhan dan kondisi anak. ${ }^{16}$

\section{Pendidikan Islam}

Pendidikan Islam pendidikan yang diselenggarakan sesuai dengan tuntunan Al-Qur'an dan Hadist Nabi agar dapat mengantarkan anak menuju kepribadian yang yang baik dari ranah jasamani maupun rohani. Pendidikan Islam ketika diselenggarakan pada lembaga harus mengedepankan akidah, psikis, spirituali, dan karakter anak didik. Para guru harus mengedepankan jiwa pembiasaan yang baik dan berakhlak mulia. ${ }^{17}$ Adapun ruang lingkup pendidikan Islam yang diterapkan di lembaga terdiri dari keserasian, keselarasan dan hubungan antara manusia dengan Rabbnya, yang dapat digagaskan dalam aspek akidah, akhlak, tarikh, ilmu fiqih, dan doa-doa yang diambil dari hadist Nabi. Selain pada hal tersebut, adanya pengajaran Al-Qur'an dapat menjadikan sebuah momentum dalam melengkapi ruang lingkup pendidikan Islam yang ada di lembaga. ${ }^{18}$ Pendidikan ini diterapkan melalui pembiasaan, percontohan, dan tahlil jika pembelajaran yang diterapkan berbentuk hifdzu. Para guru memberikan keilmuan dalam membaca, menghafal ayat suci Al-Qur'an, belajar fiqih, akidah, doa-doa harian, akhlak dengan tujuan sebagai pengembangan spiritualitas, karakter, emosional, intelektual, dan potensi anak. ${ }^{19}$

\section{Pendidikan Raudlatul Athfal (RA) bagi Anak Usia Dini}

Pendidikan Raudlatul Atfhfal (RA) merupakan salah satu jalur pendidikan anak usia dini yang berstatus formal dalam penyelenggaraannya. Hal ini telah tertuliskan dalam kebiajkan Undang-Undang No.2 Tahun 2003 mengenai sistem pendidikan nasional. Sistem pembelajaran yang ada di lembaga RA lebih mengedepannya pendidikan agama Islam sejak dini serta adanya keilmuan umum bagi anak usia dini. Sistem penyelenggaraan pendidikan RA

https://www.kemdikbud.go.id/main/blog/2020/08/kemendikbud-terbitkan-kurikulum-darurat-pada-satuanpendidikan-dalam-kondisi-khusus.

16 Ahmad Munajim and Fikriyah, "Pengembangan Kurikulum Pembelajaran Di Masa Darurat," Jurnal Dwija Cendekia: Jurnal Riset Pedagogik 4, no. 2 (2020): 285-91, https://doi.org/https://doi.org/10.20961/jdc.v4i2.45288.

${ }_{17}$ Muhammad Fathurrohman, Prinsip Dan Tahapan Pendidikan Islam (Yogyakarta: Garudawachana, 2017). hlm. 3-4

${ }_{18}$ Moh Abdullah and Moch Faizin Muflich, PENDIDIKAN ISLAM: Mengupas Aspek-Aspek Dalam Dunia Pendidikan Islam (Yogyakarta: Aswaja Presindo, 2019). hlm. 25

19 Nini Aryani, "Konsep Pendidikan Anak Usia Dini Dalam Perspektif Pendidikan Islam," Jurnal Potensia 14, no. 02 (2015): 213-30, https://doi.org/DOI: http://ddoi.org/10.24014/potensia.v1i2.3187. 
ini adalah dibawah naunagan Kementerian Agama ${ }^{20}$. Inilah yang membedakan antara PAUD/TK dan RA/BA.

Pendidikan Islam diselenggarakan atas dasar kurikulum nasional serta pengembangan pendidikan Islam atas dasar Al-Qur'an, Hadist Nabi, mutualisme pendidikan yang profesional, sarana prasarana yang memadai, serta adanya landasan materi pembelajaran yang bermutu. Pendidikan RA didirikan harus sesuai dengan keputusan Kementerian Agama No 792 tahun 2018 mengenai pedoman pendidikan Raudlatul Atfal bagi anak usia dini yang berlandaskan atas keimanan, keikhlasan, ketakwaan, ukhwah islamiyah, akidah akhlak, penunjang karakter baik sejak dini. ${ }^{21}$

Adanya implementasi nilai-nilai pendidikan yang berlandasan atas Al-Qur'an dan Hadist Nabi menjadi penunjang kesuksesan mutualisme pendidikan bagi generasi golden age. Mengenai hal tersebut, adanya suatu peranan dalam pendidikan Raudlatul Athfal bagi karakteristik dan poteni anak didik, terkhusus anak usia dini, Perannya adalah dapat menjadikan anak terbiasa dalam melakukan pembisasaan yang berhubungan dengan akhlak, akidah, ketakwaan, dan sikap empati dan simpati antara guru, orangtua dan anak didik. ${ }^{22}$

\section{METODE PENELITIAN}

Artikel ini menggunakan jenis metode penelitian kualitatif dengan analisis data deskriptif yaitu mendeskripsikan mengenai tindakan pihak lembaga RA dalam memanajemen pengembangan kurikulum darurat berbasis pendidikan Islam yang digunakan saat pandemi Covid-19. Data yang digunakan berupa data primer yang bersumber dari hasil wawancara manajemen kurikulum darurat berbasis pendidikan Islam yang bersumber dari informan dari pihak kepala sekolah RA Masyithoh Rembang, waka kurikulum, dan para guru wali kelas RA Masyithoh Rembang.

Adapun data sekunder yang digunakan dalam artikel ini adalah data dokumenter dari pedoman kurikulum darurat berbasis pendidikan Islam milik RA Masyithoh Rembang, serta artikel ilmiah yang bertemakan manajemen kurikulum dan implementasi pendidikan Islam bagi anak usia dini. Peneliti juga mewawancari beberapa orangtua wali murid RA untuk dijadikan sumber data primer tambahan agar mendapatkan data berupa evaluasi implementasi pendidikan Islam bagi anak usia dini yang tercantum dalam kurikulum darurat RA Masyithoh Rembang. Setelah data terkumpul, peneliti menganalisis seluruh data tersebut dengan analisis

${ }^{20}$ Arifah Imtihan, "Strategi PengelolaanRaudatul Atfal (RA) Menjadi Paud Unggulan," Al-Atfal: Jurnal Kajian Perkembangan Anak Dan Manajemen Pendidikan Anak Usia Dini 1, no. 1 (2018): 1-27, https://www.ejournal.stainupwr.ac.id/index.php/Al_Athfal/article/view/51.

${ }^{21}$ Ibnu Salman and Agus Widodo, "Kebijakan Peningkatan Mutu Pendidikan Raudlatul Atfal Dalam

Telaah Restra Kemenag 2015-2019," Modeling, Jurnal Program Studi PGMI 7, no. 2 (2020): 170, https://doi.org/DOI: https://doi.org/10.36835/modeling.v7i2.664.

22 Muhammedi, "Peran Raudlatul Atfal (RA) Dalam Membina Generasi Islam Yang Berkarakter," Jurnal Raudhah 5, no. 1 (2017): 1-20, https://doi.org/DOI: http://dx.doi.org/10.30829/raudhah.v5i1.139. 
data deskriptif. Tahap analisis datanya adalah peneliti mendapatkan data secara langsung di lokasi penelitian, kemudian menganalisisnya secara deskriptif yang berpacu pada penelitian terdahulu dan referensi yang serupa dengan tema. Setelah hal tersebut dilakukan, peneliti dapat mengambil kesimpulan dari pembahasan penelitian.

\section{HASIL DAN PEMBAHASAN}

Adapun hasil temuan penelitian yang bertemakan manajemen kurikulum darurat berbasis pendidikan Islam yang dilakukan oleh pendidik RA Masyithoh Rembang dapat berupa perencanaan, pengorganisasian, pelaksanaan, evaluasi kurikulum, kendala yang didapat saat guru mengiplementasi kurikulum darurat berbasis pendidikan Islam, dan keunggulan dari implementasi kurikulum berbasis pendidikan Islam bagi anak didik.

\section{Perencanaan Kurikulum Darurat Berbasis Pendidikan Islam RA Masyithoh}

Perencanaan pengelolaan kurikulum ini diterapkan berdasarkan visi, misi, tujuan, dan implementasi pendidikan anak yaitu pendidikan Islam rahamatal Lil Alamin. Ibu Kepala Sekolah RA Masyithoh menyampaikan bahwa;

"Kurikulum Darurat ini dibuat sebagai acuan dan pembantu guru dalam mempermudah jalannya pembelajaran saat pandemi mbak, terkhusus implementasi pendidikan Islam bagi anak usia dini. Kurikulum ini juga dibuat atas dasar pengembangan pembelajaran di masa pandemi Covid-19 yang meliputi susunan dari kurikulum darurat pusat pendidikan, kurikulum satuan pendidikan, kurikulum 2013 PAUD, serta kalender akademik"

Pernyataan diatas, menjelaskan bahwa kurikulum darurat RA Masyithoh dibuat dan dikembangkan sebagai landasan dasar bagi pendidik RA Masyithoh agar dapat menginplementasikan pendidikan Islam dengan mudah. Tersusunya kurikulum darurat ini berlandaskan atas pedoman kurikulum nasional, stuktur muatan kurikulum RA, kalender akademik sekolah dan penerapannya berdasakan atas aspek perkembangan anak yang ada dalam kurikulum 2013 PAUD. Selain adanya hal tersebut, waka kurikulum dan segenap pihak sekolah merencanakan kurikulum berdasarkan analisis kondisi internal maupun eksternel pada lingkungan anak dengan melihat zona lokasi tempat tinggal guru, tenaga kependidikan, dan peserta didik agar terhindar dari virus corona. Kurikulum ini direncanakan dengan mengacu pada pembelajaran anak melalui bermain, mempertimbangkan kebutuhan anak, berkesinambungan serta selalu memperhatikan teknologi informatika yang ada.

Pihak lembaga menyiapkan berkas-berkas dokumentasi berupa berkas program pengembangan lembaga, draf kurikulum, ikurikulum KTSP dan kurikulum 2013 PAUD. Setelah dokumen terkumpul, pihak lembaga mengajukan pengembangan kurikulum yang dibuat kepada pihak dinas Kementerian Agama Kabupaten Rembang agar dapat disahkan dan digunakan sebagai mana mestinya. Berikut dokumentasi dari perencanaan 
pengembangan kurikulum darurat melalui rapat penyusunan program pengembanan pembelajaran anak didik selama masa pandemi.

Gambar 1. Rapat penyusunan perencanaan kurikulum darurat berbasis Pendidikan Islam di RA Masyithoh

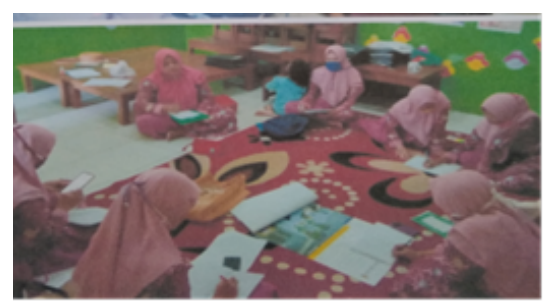

\section{Pengorganisasian Kurikulum Darurat Berbasis Pendidikan Islam RA Masyithoh}

Pengorganisasian kurikulum dibentuk dari koordinator baru yang dipilih langsung oleh ketua bagian kurikulum agar pengelolaan dan pelaksanaan kurikulum dapat berjalan dengan efektif dan efisien. Menurut bagian waka pengembang kurikulum darurat RA menyatakan bahwa;

"Guru RA yang ditunjuk sebagai penangung jawab terdiri dari ketua, wakil ketua, sekertaris, bendahara serta anggota pengembangan kurikulum. Tujuannya ya sebagai pembantu, dan tim sukses dalam pengimplementasian kurikulum. Jika ada koordinasi pusat, maka yang bertanggung jawab adalah pihak-pihak tersebut. para anggota sudah banyak membantu dan baik dalam mengembangkan kurikulum darurat berdasarkan penggunaan kurikulum KTSP, K13, indikator pencapaian perkembangan anak dan implementasi tema yang menarik saat pembelajaran."

Dalam pernyataan diatas, menjelaskan bahwa adanya suatu kerjasama antara waka kurikulum, pihak pengembang kurikulum dan para guru wali kelas dalam merusmuskan dan mengembangkan kurikulum darurat menjadi kurikulum pendidikan Islam bagi anak usia dini yang efektif untuk digunakan. Tugas penanggung jawab tersebut adalah mengembangkan kurikulum berdasarkan hasil musyawarah dan evaluasi dari pengawas atau penilik RA ketika masa pambelajaran daring. Penanggung jawab kurikulum juga wajib menerapkan dasar kurikulum nasional kedalam kurikulum darurat. Pengembang kurikulum juga menyesuaikan pendidikan yang diajarkan selama pandemi berdasarkan kalender akademik yang ada di lembaga. Adapun penyusunan kalender akademik berdasarkan bulan aktif belajar anak. Selain hal tersebut adanya implementasi kegiatan pendidikan yang direncanakan dalam kalender akademik. Para pengembang kurikulum juga mencantumkan metode pelaksanaan pendidikan anak dalam penyusunan kalender akademik agar memudahkan guru untuk membuat silabus pembelajaran. Metode yang digunakan adalah metode daring yaitu pembelajaran dari jarak jauh yang disesuaikan berdasakan SK kementerian pendidikan pusat mengenai pembelajaran daring. 


\section{Pelaksanaan Kurikulum Darurat Berbasis Pendidikan Islam RA Masyithoh}

Pelaksanaan program pendidikan harus berpedoman akan silabus dari dokumendokumen yang terdiri dari visi, misi, tujuan pendidikan, program pembelajaran, indikator perkembangan anak serta capaian perkembangan anak yang disesuaikan berdasarkan usia anak yang dirancang mulai program tahunan, semesteran, mingguan dan harian. Bentuk penilaian pembelajaran anak juga harus diterapkan. Bagian waka pengembangan kurikulum menyatakan bahwa;

"Pembelajaran anak dalam kurikulum dilakukan dari rumah pada pukul 07.00 sampai pukul 10.00 WIB melalui whatsApp group dan vidio call. Adanya kerjasama antara orangtua dan guru dalam melaksanakan pembelajaran yang telah disepakati dalam kurikulum darurat masa pandemi."

"Harapan dari adanya pelaksanaan manajemen pengembang kurikulum darurat ini adalah dapat menjadikan pembelajaran anak menjadi mudah di masa pandemi. Hal ini dengan dibuatnya SOP berupa standart Operasional Prosedur dalam pelaksanaan pendidikan Islam melalui kurikulum darurat masa pandemi."

Pernyataan diatas, menjelaskan bahwa pelaksanaan kurikulum darurat disesuaikan dengan surat keputusan kementerian pendidikan mengenai pembelajaran selama pandemi dilakukan dari rumah masing-masing anak. RA Masyithoh Rembang mengimplementasikan kurikulum ini dengan berasaskan atas program Tahuan, Semesteran, Mingguan, dan Harian. Adapun implementasi pembelajaran diterapkan pada pukul 07.00 sampai pukul 10.00 WIB melalui media sosial WhatsApp dan vidio call. Adanya SOP baru terkait pengambilan media pembelajaran, parenting antara guru dan orangtua, serta pembagian evalausi raport hasil belajar anak selama satu minggu yang beralokasikan di RA Masyithoh Rembang dengan menggunakan protokol kesehatan covd 19. SOP yang digunakan mencangkup beberapa aspek, diantara adalah; Judul SOP berupa program pengambilan materi, pelaksanaan pendidikan, dan rapor anak disetiap mingguannya; Tujuan SOP yaitu agar dapat memudahkan anak untuk melakukan pembelajaran daring dari rumah serta para orangtua dapat mengetahui perkembangan anak setiap mingguannya; Referensi yang digunakan dalam pelaksanaan SOP Kurikulum darurat yang terdiri dari Permendiknas No.146 tahun 2014, Keputusan Direktur Jendral Pendidikan Islam No 2791 tahun 2020 serta adanya visi, misi, dan tujuan RA Masyithoh Rembang; Pihak yang terkait dari guru kelas/kelompok, orangtua/wali; dan Dokumen yang digunakan berupa RPPH serta rapor penilaian hasil belajar kegiatann mingguan anak secara daring.

\section{Evaluasi Kurikulum Darurat Masa Pandemi RA Masyithoh}

Evaluasi kurikukulum darurat didapat dari keterlibatan Kementerian Agama daerah, ketua yayasan, para pengembang kurikulum dan para guru yang bekerjasama mengembangkan kurikulum dengan efektif. Para guru sangat antusias dan berhasil dalam memenejemen kurikulum yang dilakukan sebagai cikal bakal pendidikan Islam bagi anak usia 
dini selama masa pandemi. Evaluasi dilakukan melalui hasil konferensi dalam kegiatan rapat evaluasi kurikulum yang dilaksanakan melalui evaluasi kurikulum e-learning dari kementerian agama daerah Rembang dan para guru IGRA. Adanya dokumen pengantar kurikulum, saran dari pendidik dan pengawas, serta hasil kesepakatan bersama membuat kurikulum darurat dapat diterima dengan baik oleh Kementerian Agama untuk digunakan sebagai pedoman pendidikan Islam bagi anak usia dini. Hasil penelitian yang ada, maka dapat dijadikan bagan manajemen pengembangan kurikulum darurat berbasis pendidikan Islam sebagai berikut;

Tabel 1. Manajemen perencanaan dan pengorganisasian kurikulum darurat RA Masyithoh selama Covid-19

\begin{tabular}{|c|c|}
\hline Perencanaan & Pengorganisasian \\
\hline $\begin{array}{l}\text { Adanya dokumen Visi, Misi, Tujuan, } \\
\text { dan dokumen penting penunjang } \\
\text { kurikulum darurat }\end{array}$ & $\begin{array}{l}\text { Pembuatan tim sukses dari ketua, sekertaris, } \\
\text { bendahara,waka kurikulum, anggota } \\
\text { pengembang kurikulum dengan tujuan } \\
\text { membantu jalannya kesuksesan saat } \\
\text { implementasi kurikulum }\end{array}$ \\
\hline $\begin{array}{l}\text { Penyerahan dokumen kepada } \\
\text { Kemenag daerah agar disahkan } \\
\text { sebagai pedoman pndidikan Islam } \\
\text { anak usia dini selama masa pandemi }\end{array}$ & $\begin{array}{l}\text { Pembuatan kalender akademik pendidikan } \\
\text { selama masa pandemi dengan tujuan } \\
\text { sebagai pedoman } \\
\text { pendidikan Islam RA }\end{array}$ \\
\hline
\end{tabular}

Tabel 2. Manajemen pelaksanaan dan evaluasi kurikulum darurat RA Masyithoh selama Covid-19

\begin{tabular}{|c|c|}
\hline Pelaksanaan & Evaluasi \\
\hline $\begin{array}{l}\text { Penggunaan Silabus pendidikan Islam } \\
\text { berupa rancangan program tahunan, } \\
\text { semester, mingguan, dan harian } \\
\text { dengan tujuan agar pelaksanaan } \\
\text { implementasi kurikulum dapat } \\
\text { berjalan dengan efektif dan efisien }\end{array}$ & $\begin{array}{l}\text { Mengikuti rapat evaluasi MGMP, evaluasi } \\
\text { kurikulum E -learning yang dilakukan oleh } \\
\text { pengawas atau penilik selama satu bulan } \\
\text { sekali dengan tujuan mengetahui hasil } \\
\text { penyelenggaraan kurikulum berbasis } \\
\text { pendidikan Islam saat pandemi }\end{array}$ \\
\hline $\begin{array}{l}\text { Pembuatan SOP } \\
\text { pengimplementasian terhadap } \\
\text { berupa program pengambilan media, } \\
\text { materi dan penyerahan raport } \\
\text { mingguan anak selama seminggu } \\
\text { pembelajaran daring }\end{array}$ & \\
\hline
\end{tabular}

\section{Kendala Implementasi Kurikulum Darurat Berbasis Pendidikan Islam RA Masyithoh}

Cakupan pendidikan Islam dalam kurikulum darurat yang diterapkan di lembaga RA Masyithoh Rembang terdiri dari pembelajaran hifdzul Qur'an, sirrah Nabawiah, hadist Nabi yang meliputi hadist kasih sayang, menjaga lisan, jangan marah, kebersihan dan hasil pendek lainnya. Selain pembelajara tersebut, pendidikan Islam yang diterapkan berupa pendidikan akhlak yang terdiri dari pendidikan berbudi luhur dengan selalu berbuat baik, jujur,sopan 
santun kepada orang lain. Pendidikan Islam di RA Masyithoh Rembang mengajarkan akan kebiasan anak dalam berdzikir kepada Allah dengan membiasakan anak untuk selalu meladzkan kalimat tauhid, tahmid, tasbih, tahlil dan istigfar. Pembelajaran dimulai pukul 07.00 sampai pukul 10.30 WIB dari rumah masing-masing melalui vidio call secara bergantian dan pengiriman hasil belajar anak.

Adanya kendala berupa kurangnya kekuatan sinyal internet, kurangnya interaksi guru dan anak saat proses pembelajaran, kurangnya kapasitas memori HP sehingga penilaian dan vidio lambat untuk diupload pada media sosial. Orangtua membimbing anak secara langsung ketika anak sedang melakukan proses pembelajaran. Pihak Waka kurikulum, kepala sekolah, dan segenap guru wali kelas mempunyai penanggulangan dalam menanggulangi kendala implementasi kurikulum darurat berbasis pendidikan Islam ini dengan cara adanya kerjsama atara guru dan orangtua dalam membimbing anak untuk belajar.

Adapun pihak sekolah memberikan bimbingan belajar personal dan berkelompok kepada anak-anak yang kurang pemahaman atas pembelajaran. Para guru juga membimbing, dan memotivasi anak saat parenting setiap hari Sabtu.berikut dokumentasi implementasi bimbingan belajar anak dan implementasi parenting yang diterapkan dalam program kurikulum darurat masa pandemi RA Masyithoh Rembang. Berikut gambar implementasi kegiatan program bimbingan belajar anak dan parenting bagi anak dan orangtua pada hari Sabtu.

Gambar 2. Kegiatan parenting dan pengambilan media RA Masyithoh

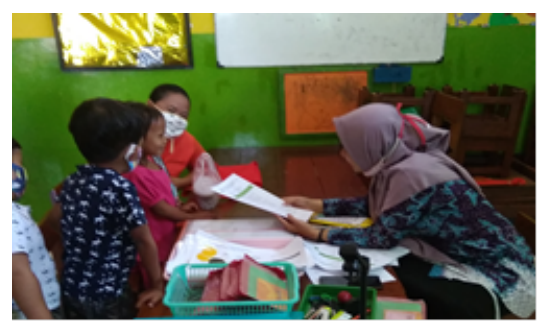

Gambar 3. Kegiatan bimbingan belajar yang dilakukan oleh guru dan anak melalui vidio call

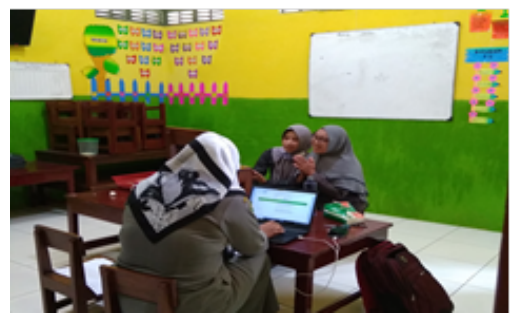

Adapun hasil analisis data dari data kendala dan penanggulangan implementasi kurikulum darurat RA Masyithoh dapat dilihat pada tabel dibawah; 
Tabel 3. Kendala dan Penanggulangan kurikulum darurat berbasis pendidikan Islam selama pandemi Covid-19

\begin{tabular}{|l|l|}
\hline \multicolumn{1}{|c|}{ Kendala } & \multicolumn{1}{|c|}{ Penanggulangan } \\
\hline Kekuatan sinyal yang rendah & $\begin{array}{l}\text { Adanya kerjasama antara pihak sekolah dan } \\
\text { orangtua dalam pengimplentasian kurikulum } \\
\text { darurat berbasis pendidikan Islam selama } \\
\text { pandemi Covid-19. }\end{array}$ \\
\hline $\begin{array}{l}\text { Implementasi pendidikan Islam } \\
\text { yang kurang maksimal karena } \\
\text { kurang bimbingan dari guru secara } \\
\text { langsung }\end{array}$ & $\begin{array}{l}\text { Adanya bimbingan belajar individual melalui } \\
\text { vidio call antar murid yang kurang dalam } \\
\text { pemahaman materi pelajaran }\end{array}$ \\
\hline & $\begin{array}{l}\text { Adanya motivasi anak setiap mingguannya } \\
\text { melalui program parenting setiap hari Sabtu. }\end{array}$ \\
\hline
\end{tabular}

\section{Keunggulan Implementasi Kurikulum Darurat Berbasis Pendidikan Islam RA Masyithoh}

Adanya keunggulan dari implementasi kurikulum darurat dari beberapa pihak. Pertama, dari pihak sekolah ( guru wali kelas ) yang menyatakan bahwa;

'Penerapan kurikulum baru ini dapat meningkatkan kinerja guru RA selama pandemi, dengan selalu merekap hasil evaluasi anak selama seminggu. Pembelajaran dapat disederhanakan berdasarkan waktu pelaksanaan sesuai dengan tema yang ditentukan, tidak teralu rumit dan media yang digunakan sesuai dengan ketersediaan di rumah"

Pernyataan pihak guru diatas, menjelaskan bahwa adanya peningkatan dalam pengimplementasian kurikulum darurat saat pembelajaran dilakukan. Peningkatannya adalah ada pada kinerja guru yang terarahkan. Hasil yang didapat adalah para guru antusias, serta adanya rekapan evaluasi pendidikan Islam yang dapat dibuat dan diberikan kepada orangtua setiap mingguannya. Selain hal tersebut, pembelajaran yang diimplementasikan dalam kurikulum berpusat pada tema yang sederhana, kegiatan yang menarik dan sesuai dengan kebutuhan dan kondisi anak di rumah. Fungsi guru dalam penerapan ini adalah tidak lain sebagai pembantu dan permudah guru kepada orangtua anak dalam mempersiapkan dan membimbing jalannya pembelajaran saat daring.

Adapun dari pihak orangtua juga memiliki pendapat mengenai keunggulan dari implementasi kurikulum darurat berbasis pendidikan Islam. Hasil analisis data penelitian menyatakan bahwa para orangtua tidak keberatan dalam pengimplmentasian kurikulum. Adanya timbal balik pada karakteristik anak, yaitu anak dapat belajar akan kemandirian, hidup sederhana, dan berani dalam berinteraksi. Keunggulan yang lainnya dengan adanya implementasi kurikulum darurat berbasis pendidikan Islam ini adalah orangtua dapat memantau perkembangan anak melalui hasil rapor belajar anak selama satu minggu yang diberikan melalui program kegiatan parenting pada hari Sabtu di sekolah. 


\section{PEMBAHASAN}

\section{Implikasi Manajemen Perencanaan Pengembangan Kurikulum Darurat saat Pandemi Covid-19}

Implikasi manajemen kurikulum digunakan sebagai rancangan pengelolaan kurikulum darurat. Pemerintah menetapkan sistem pengembangan kurikulum tanggap darurat yang berguna bagi guru sebagai pedoman dasar pembelajaran secara daring. Adanya pegimplementasian kurikulum ini disesuaikan dengan kebutuhan sekolah dan anak didik. ${ }^{23}$ Pihak lembaga, baik dari kepala sekolah maupun para guru ikut andil dalam merancang, merencanakan, melaksanakan, menghendel dan mengevaluasi jalannya implementasi kurikulum terhadap pembelajaran anak di masa pandemi. ${ }^{24}$ Adanya penelitian tersebut, maka manajemen ini dapat terealisasikan dengan baik terkhusus manajemen kurikulum darurat di RA Masyithoh Rembang. Penggunaan kurikulum darurat pada masa ini sangat dianjurkan untuk digunakan sebagai pedoman pembelajaran saat pandemi Covid-19. Adanya hal tersebut, maka dapat diterapkannya pengembangan kurikulum darurat melalui strategi menejemen kurikulum yang ada di RA Masyithoh.

Studi penelitian menyatakan bahwa pengembangan kurikulum diterapkan guna mengembangkan pembelajaran menjadi saintifik integratif dengan pembelajaran yang bersifat menyeluruh guna meningkatkan wawasan peserta didik, serta adanya suatu instruksi pedoman pembelajaran yang bersifat memudahkan anak. ${ }^{25}$ Lembaga RA Masyithoh Rembang telah mengimplementasikan pengembangan kurikulum lama dengan kurikulum baru yaitu kurikulum darurat masa pandemi dengan sederhana sesuai dengan kebutuhan anak. Sebuah penelitian menyatakan bahwa ketika hendak melakukan suatu program manejemen pengembangan kurikulum, pihak lembaga terlebih dahulu merencanakan, melaksanakan, dan mengevaluasi kurikulum yang telah dikembangkan sebagai sarana untuk menuju pendidikan yang maju. ${ }^{26}$ Adanya perbedaan penelitian ini dengan artikel penelitian pada sesi kali ini.

Penelitian sesi kali ini mengimplementasikan pengembangan kurikulum darurat dengan merumuskan sebuah perencanaan, pengorganisasian, pelaksanaan, serta evaluasi guna meningkatkan efektivitas pembelajaran pendidikan Islam selama masa pandemi. Jika penelitian yang dijadikan sumber literatur hanya merumuskan suatu perencanaan,

23 Kemdikbud, “Kepmendikbud Nomor 719/P/2020 Tentang Pedoman Pelaksanaan Kurikulum Pada Satuan Pendidikan Dalam Kondisi Khusus.”,,, hlm.9

24 Erni Ats-Tsaur dan Munastiwi, "Strategi Kepala Madrasah dalam Menentukan Kebijakan Pembelajaran Era Covid 19: Studi Kausu Kepala Madrasah Ibtidaiyah Pondok Gedang," ElementerIs: Jurnal Ilmiah Pendidikan Dasar Islam 2, $\quad$ no. 2 (2020): https:// doi.org/http://dx.doi.org/10.33474/elementeris.v2i2.8679.

25 A. Sulaeman, "Pengembangan Kurikulum 2013 Dalam Paradigma Pembelajaran Kontemporer," $\begin{array}{llll}\text { Islamadina } & \text { XIV, no. } & \text { (2015): 71-95, }\end{array}$ http://jurnalnasional.ump.ac.id/index.php/ISLAMADINA/article/view/1669.

26 Dedi Lazwardi, "Manajemen Kurikulum Sebagai Pengembangan Tujuan Pendidikan," Kependidikan Islam 7, no. 1 (2017): 99-112. 
pelaksanaan, dan evaluasi, tanpa adanya suatu koordinasi dalam mengembangkan manajemen kurikulum pendidikan. Studi penelitian mengungkapkan bahwa jika lembaga pendidikan menginginkan hasil yang berkualitas, maka diperlukannya manajemen kurikulum yang profesional agar hasilnya dapat efektif dan efisien. ${ }^{27}$ Pihak lembaga RA Masyitoh merencanakan kurikulum darurat masa pandemi dengan mengumpulkan dan menganalisis dokumen-dokumen penting yang berhubungan erat mengenai pembelajaran anak usia dini yang diimplementasikan melalui jarak jauh atau daring. Adanya pengesahan dari dinas Kemenag terhadap dokumen visi, misi, tujuan, program pengembang pendidikan Islam, Indikator perkembangan anak, serta surat keputusan Direktur Jendral Pendidikan Islam No 2791 tahun 2020 tentang pendidikan anak inilah sebuah perencanaan manajemen kurikulum darurat dapat diterapkan sebagai tindakan untuk memanajemen pengembangan kurikulum saat pandemi Covid-19.

\section{Implementasi Pengorganisasian dan Pelaksanaan Kurikulum Darurat Covid-19}

Adanya pengorganisasian dalam manajemen pendidikan Islam dibuat agar dapat menciptakan kerjasama antara guru dengan kepala sekolah agar pengembangan kurikulum berjalan dengan efektif dan efisien. ${ }^{28}$ Pengorganisasian yang diterapkan di RA Masyithoh dilakukan oleh seluruh staf pengembang kurikulum, baik dari ketua pengembang kurikulum sampai anggota pengembang kurikulum. Tugas pengembang kurikulum adalah membuat program kerja berdasarkan kalender akademik agar dapat terlasakna dengan baik dan terstruktur. Studi penelitian terkait manajemen kurikulum pendidikan Islam masa pandemi mengungkapkan bahwa, jika ingin melaksanakan manajemen kurikulum di suatu Madrasah, maka hal yang perlu diperhatikan adalah persiapan media, materi, dan bahan ajar dalam mengimplementasikan pembelajaran daring ${ }^{29}$. Penelitian diatas berbeda dengan penelitian pada sesi kali ini.

Pelaksanaan manajemen kurikulum berbasis pendidikan Islam masa pandemi di RA Masyithoh Rembang dilalui dengan pembuatan program pembelajaran yang dibuat dari program tahunan, semesteran, mingguan, sampai harian. Namun pada masa sekarang, pelaksanaan pengembangan kurikulum dibuat berdasarkan program harian dengan membuat kegiatan yang menarik, sesuai dengan kebutuhan anak. Adanya pembuatan SOP terkait

27 Arif Khoirudin, "Manajemen Kurikulum Dalam Meningkatkan Mutu Pendidikan," Tribakti Jurnal Pemikiran Kislaman 24, no. 1 (2013): 1-22, https://doi.org/https://doi.org/10.33367/tribakti.v24i1.126.

${ }^{28}$ Fathor Rachman, "Managemen Organisasi Dalam Perspektif Al-Qur'an dan Hadist," Jurnal Studi Keislaman 1 , no. 2 http://ejournal.kopertais4.or.id/madura/index.php/ulumuna/article/view/1628/1202.

29 Ayu Wilatikta, "Manajemen Kurikulum Pendidikan Agama Islam Jenjang Pendidikan Dasar: Kontekstualisasi Strategi Pembelajaran Semasa Pandemi," Jurnal Ilmu Agama Islam 2, no. 2 (2020): 1-12, http://journal.uml.ac.id/TL/article/view/206. 
kegiatan pengembangan kurikulum yang melibatkan orangtua, guru dan anak dalam mengimplementasikan proses pembelajaran daring.

\section{Implikasi Evaluasi Kurikulum Darurat Covid-19 Lembaga Pendidikan PAUD}

Studi penelitian terkait evaluasi kurikulum pendidikan menyatakan bahwa jika kita ingin mengevaluasi kurikulum pendidikan, maka hendaknya ada sebuah metode dalam mengevaluasinya. Penelitian tersebut menggunakan metode evaluasi countenan stake, yang meliputi evaluasi pendahuluan, proses, dan hasil. ${ }^{30}$ Penelitian pada sesi kali ini memiliki perbedaan dalam membahas evaluasi kurikulum darurat masa pandemi di RA Masyithoh. Peneliti tertarik menggunakan model evaluasi CIPP dikarekan prosedurnya yang lengkap sesuai dengan program manajemen kurikulum darurat masa pandemi.

Adapun peneliti menganalisis evaluasi kurikulum ini melalui tahapan evaluasi contex, input, process, dan product. Suatu penelitian menyatakan bahwa penggunaan model CIPP dalam menganalisis evaluasi kurikulum merupakan teknik yang cocok dalam mengevaluasi kurikulum berdasarkan sumber daya manusia yang terlibat serta proses pelaksanaan yang menghasilkan sebuah produk dari capaian yang diperoleh dalam merencanakan dan mengembangkan kurikulum. ${ }^{31}$ Evaluasi kurikulum di RA Masyithoh jika ditinjau dari evaluasi konteks dan input maka hasilya adalah baik dan mendapatkan nilai unggul se Kecamatan Rembang. Hal ini didasari oleh adanya pedoman KTSP PAUD Tahun 2013, surat keputusan dari Jendral Pendidikan Islam No 2791 tahun 2020 perihal rancangan kurikulum darurat dan didasari oleh enam aspek perkembangan anak yang disesuaikan berdasarkan kebutuhan anak.

Adanya kerjasama pihak lembaga sekolah yang terdiri dari ketua waka kurikulum hingga anggota pengembang kurikulum yang terlibat dalam evaluasi input. Teknik input digunakan dalam mengevaluasi stakeholder yang bekerja dalam mengembangkan kurikulum, termasuk para guru RA, kepala sekolah, anak didik, tenaga kepedidikan dan pemerintah. ${ }^{32}$ Jika kita merujuk kepada penelitian ini, maka evaluasi kurikulum darurat RA Masyithoh diadakan dalam rapat komite dan bimtek kurikulum e-learning yang dihadiri oleh beberapa pegawas, ketua yayasan, kementerian Agama dan segenap guru IGRA di Kabupaten Rembang. Hasil evaluasi menyatakan bahwa penggunaan kurikulum darurat di masa pandemi sangat dianjurkan untuk dibuat, guna mempermudah guru dalam menjalankan tugas sebagai pengajar RA pada masa pandemi Covid-19.

30 Sri Budiani and Sudarmin, "Evaluasi Implementasi Kurikulum 2013di Sekolah Pelaksana Mandir," Innovative Journal of Curriculum and Educational Technology 6, no. 1 (2017): 45-57, https://doi.org/10.15294/IJCET.V6I1.15998.

31 Ayu Luhanarky, "Evaluasi Kurikulum Pembelajaran Matematika Permulaan di TK Negeri Pembina Cirebon", Awlady: Jurnal Pendidikan Anak 5, no. 2 (2019): 16-33, https://doi.org/10.24235/awlady.v5i2.5128.

32 Maria Goreti V Anamara, "Implementasi Evaluasi Program Standart PAUD," Jurnal Pendidikan Anak Usia Dini 8, no. 2 november (2014): 301-15, https://doi.org///doi.org/10.21009/JPUD.082.010. 
Adapun proses evaluasi dilakukan oleh pengawas dan direview kembali oleh pihak pengembang kurilum PAUD. Setelah diterapkannya evaluasi proses, maka langkah selanjutnya dalam mengevaluasi kurikulum adalah melalui evaluasi produk. Evaluasi produk diimplementasikan melalui kurikulum untuk mendapatkan informasi mengenai hasil dari penilaian program yang sudah tertuliskan. ${ }^{33}$ Jika dikaitkan pada kurikulum darurat RA Masyithoh, maka evaluasi yang didapat adalah para guru merasa terbantu dikarenakan setiap mingguannya dapat menjalankan penilaian pembelajaran anak secara berkesinambungan. Disamping itu pula anak didik dan orangtua dapat mengetahui hasil belajar anak selama satu minggu secara langsung. Orangtua juga terbantu dikarenakan adanya pengimplementasian pembelajaran kemandirian, kedisiplinan.

\section{Keunggulan, Kendala dan Penanggulangan Implementasi Kurikulum Covid-19}

Adanya suatu keunggulan dalam penggunaan kurikulum darurat selama pandemi di RA Masyihoh. Keunggulannya terletak pada sistematika pendidikan yang menganjurkan anak untuk selalu tidak meninggalkan budaya keislaman, selalu menggunakan alat teknologi sebagai alat belajar anak, serta adanya penyesuaian karakter budaya anak saat pengimplementasian pendidikan Islam melalui kurikulum darurat RA. Hasil penelitian ini dikuatkan oleh penelitian yang menyatakan bahwa sistem pendidikan Islam yang diajarkan di lembaga pendidikan, harus berimplementasikan pada kebutuhan anak, nilai-nilai keislaman sesuai dengan dasar bangsa dan negara yang disesuaikan dengan kondisi budaya disetiap umat Islam. ${ }^{34}$

Fungsi pendidikan Islam dalam kurikulum sebagai wadah untuk mengembangkan kepribadian anak dengan bersumber pada pendidikan akidah akhlak pada pembelajaran anak di sekolah. ${ }^{35} \mathrm{Hal}$ ini juga serupa dengan adanya implementasi pendidikan Islam yang di terapkan di RA Masyithoh Rembang berupa pendidikan akidah dan karakter anak. Penelitian mengungkapkan bahwa pendidikan karakter berbasis religiutas yang di terapkan di lembaga RA harus bersumber pada kurikulum pembelajaran berdasarkan mutualisme pendidikan yang berfokus pada perencanaan, pengorganisasian, dan evaluasi. ${ }^{36}$ Melalui penelitian ini, maka adanya suatu keunggulan dalam implementasi kurikulum berbasis pendidikan Islam yang menjelaskan bahwa kurikulum dibuat agar dapat mempermudah jalannya pembelajaran selama masa pandemi. Jika ada suatu keunggulan, maka adanya suatu kendala dalam

33 Ahmad Sahal Fuadi and M Anas, "Implementasi Model CIPP Dalam Evaluasi Kurikulum 2013 Pendidikan Ekonomi," 2019, 316-24.

34 Erni Munastiwi and Marfuah Marfuah, "Islamic Education in Indonesia and Malaysia: Comparison of Islamic Education Learning Management Implementation,” Jurnal Pendidikan Islam 8, no. 1 (2019): 1-26, https://doi.org/10.14421/jpi.2019.81.1-26.

35 Mansur, Pendidikan Anak Usia Dini Dalam Islam (Yogyakarta: Pustaka Pelajar, 2005). hlm. 54

36 Fitria Fauziah and Hasanah Erni Munastiwi, "Pengelolaan Pendidikan Karakter Religius Melalui Metode Pembiasaan Di Taman Kanak-Kanak," Age Jurnal Ilmiah Tumbuh Kembang Anak Usia Dini 4, no. 1 (2019): 35-46, http://ejournal.uin-suka.ac.id/tarbiyah/index.php/goldenage/article/view/2359. 
pengimplementasiannya. Kendala yang didapat dalam penelitian ini adalah ada pada penggunaan kapasitas internet, yaitu baik buruknya sinyal yang ada di daerah masing-masing. Bukan hanya itu saja, para guru merasa kesulitan dalam mengelola, membimbing jalannya pendidikan Islam selama masa pandemi. Hal ini tentunya adanya suatu dorongan dan bimbingan dari orangtua saat pembelajaran dimulai.

Penelitian ini diperkuat oleh penelitian tentang pola kerjasama antara guru dan orangtua dalam menjalankan pendidikan selama masa pandemi Covid-19. Hasil penelitian menyatakan bahwa adanya kesulitan dalam menumbuhkan karakter anak ketika pembelajaran jarak jauh, terkendala pada sinyal jaringan sosial, pola kerjasama bimbingan antara guru dan orangtua yang minim dikarenakan waktu kesenggangan orangtua. ${ }^{37}$ Jika kita analisis melalui penelitian ini, maka adanya suatu perbedaan dalam hasil penelitian yang diterapkan oleh peneliti. Perbedaannya terletak pada implemenasi evaluasi program kerja antara guru dan orangtua. Program evaluasi, bimbingan guru dan orangtua di RA Masyithoh berjalan dengan baik. Walaupun adanya suatu kendala dalam implementasi pendidikan, para guru tetap dapat mengimplementasikannya dengan baik melalui partemuan rutin setiap seminggu sekali. Dengan adanya hal tersebut, maka segala kendala dalam implementasi kurikulum dapat ditanggulangi dengan baik melalui musyawarah bersama antara guru dan orangtua serta adanya kerjasama antara kedua belah pihak.

\section{KESIMPULAN}

Hasil penelitian menyatakan bahwa adanya manajemen kurikulum darurat berbasis Pendidikan Islam selama masa pandemi Covid-19 yang diterapkan di lembaga RA Masyithoh Rembang. Manajemen kurikulum darurat ini terdiri dari perencanaan, pengorganisasian, pelaksanaan, dan evaluasi. Perencanaan dalam manajemen kurikulum berbasis pendidikan Islam didapat dari visi, misi, tujuan sekolah, prinsip pengembangan kurikulum yang disesuaikan oleh kurikulum KTSP, Kurikulum 2013 PAUD, Surat Keputusan Jendral Pendidikan Islam 2020 serta STPPA dalam merencanakan program pembelajaran daring.. Adapun pengorganisasian manajemen ini melalui tanggung jawab pengembang kurikulum, serta terprogramnya kegiatan pendidikan dalam kalender akademik yang melibatkan para guru, anak didik dan orangtua wali murid. Program pembaruan didapat dari susunan SOP kegiatan mingguan berupa pengambilan media, program parenting, dan perapotan hasil belajar anak selama satu minggu. Hasil evaluasi menyatakan bahwa adanya antuasias para guru dalam menilai kegiatan pendidikan anak selama pandemi Covid-19. Penilaian dilakukan setiap hariannya dan perapotan dilakukan setiap seminggu sekali. Hambatannya ada pada

${ }^{37}$ Laila Wardati and Ade Khairunisa, "Pola Kerjasama Guru Dan Orang Tua Pada Masa Pandemi Covid 19 Di RA Masjid Agung Medan Polonia," Jumal Pendidikan Islam Al Ulum 1, no. 2 (2020): 107-51, https:// doi.org/10.30596/al-ulum.v. 
kesulitan guru dalam mengimplementasikan pendidikan Islam secara langsung kepada anak. Orangtua merasa terbantu dan senang dengan adanya kurikulum darurat masa pandemi. Anak-anak dapat terlatih dalam kemandirian, kedisiplinan saat pendidikan dilaksanakan. Adanya hasil penelitian ini, maka para pendidik dimasa sekarang hendaknya selalu menerapkan kerjasama dalam pengimplementasian pembelajaran selama pandemi. Hal ini dilakukan guna menanggulangi kendala yang didapat saat pembelajaran daring, serta himbuan kepada pendidik agar tetap memotivasi anak agar selalu semanga saat pembelajaran daring dilaksanakan.

\section{DAFTAR PUSTAKA}

A. Sulaeman. "Pengembangan Kurikulum 2013 Dalam Paradigma Pembelajaran Kontemporer." Islamadina XIV, no. 1 (2015): 71-95. http://jurnalnasional.ump.ac.id/index.php/Islamadina/article/view/1669.

Abdullah, Moh, and Moch Faizin Muflich. Pendidikan Islam: Mengupas Aspek-Aspek Dalam Dunia Pendidikan Islam. Yogyakarta: Aswaja Presindo, 2019.

Ahmad, Mushlih, Rahimah dkk. Analisis Kebijakan PAUD: Mengungkap Isu-Isu Menarik Seputar AUD. Wonosobo: Penerbit Bangku Bumi, 2018.

Anamara, Maria Goreti V. "“Implementasi Evaluasi Program Standart PAUD,." Jurnal Pendidikan Anak Usia Dini 8, no. 2 november (2014): 301-15. https://doi.org///doi.org/10.21009/JPUD.082.010.

Arifin, Zainal. Konsep Dan Model Pengembang Kurikulum. Bandung: Remaja Rosda Karya, 2011.

Aryani, Nini. "Konsep Pendidikan Anak Usia Dini Dalam Perspektif Pendidikan Islam." Jurnal Potensia 14, no. 02 (2015): 213-30. https://doi.org/doi: http://ddoi.org/10.24014/potensia.v1i2.3187.

Ats-Tsaur dan Munastiwi, Erni. "Strategi Kepala Madrasab dalam Menentukan Kebijakan Pembelajaran Era Covid 19: Studi Kausu Kepala Madrasah Ibtidaiyah Pondok Gedang." ElementerIs: Jurnal Ilmiah Pendidikan Dasar Islam 2, no. 2 (2020): 1-8. https://doi.org/http://dx.doi.org/10.33474/elementeris.v2i2.8679.

Baharuddin, and Mohammad Makin. Manajemen Pendidikan Islam: Transformasi Menuju Sekolah/Madrasah Yang Unggul. Malang: UIN Maulana Malik Ibrahim Malang Press, 2010.

Budiani, Sri, and Sudarmin. "Evaluasi Implementasi Kurikulum 2013di Sekolah Pelaksana Mandir." Innovative Journal of Curriculum and Educational Technology 6, no. 1 (2017): 45-57. https://doi.org/10.15294/ijcet.V6I1.15998.

Fathurrohman, Muhammad. Prinsip Dan Tahapan Pendidikan Islam. Yogyakarta: Garudawachana, 2017.

Fauziah, Fitria, and Hasanah Erni Munastiwi. "Pengelolaan Pendidikan Karakter Religius Melalui Metode Pembiasaan Di Taman Kanak-Kanak." Age Jurnal Ilmiah Tumbub Kembang Anak Usia Dini 4, no. 1 (2019): 35-46. http://ejournal.uinsuka.ac.id/tarbiyah/index.php/goldenage/article/view/2359.

Fuadi, Ahmad Sahal, and M Anas. "Implementasi Model CIPP Dalam Evaluasi Kurikulum 2013 Pendidikan Ekonomi," 2019, 316-24.

Gesang, Eca, and dkk. Manajemen Pengembangan Pendidikan Anak Usia Dini. Yogyakarta: Hijaz Pustaka Mandiri, 2020.

Hadion Wijoyo, Irjus Indrawan. "Model Pembelajaran Menyongsong New Era Normal Pada 
Lembaga Paud Di Riau." Jurnal Sekolah (JS) 4, no. 3 (2020).

Imtihan, Arifah. "Strategi PengelolaanRaudatul Atfal (RA) Menjadi Paud Unggulan." AlAtfal: Jurnal Kajian Perkembangan Anak Dan Manajemen Pendidikan Anak Usia Dini 1, no. 1 (2018): $1-27$. https://www.ejournal.stainupwr.ac.id/index.php/Al_Athfal/article/view/51.

Kemdikbud. "Kemendikbud Terbitkan Kurikulum Darurat Pada Satuan Pendidikan Dalam Kondisi Khusus.” https://www.kemdikbud.go.id/, 2020. https://www.kemdikbud.go.id/main/blog/2020/08/kemendikbud-terbitkankurikulum-darurat-pada-satuan-pendidikan-dalam-kondisi-khusus.

. "Kepmendikbud Nomor 719/P/2020 Tentang Pedoman Pelaksanaan Kurikulum Pada Satuan Pendidikan Dalam Kondisi Khusus." Www.Kemdikbud.Go.Id, no. 022651 (2020): 9. https://www.kemdikbud.go.id/main/blog/2020/08/kemendikbud-terbitkankurikulum-darurat-pada-satuan-pendidikan-dalam-kondisi-khusus.

Khoirudin, Arif. "Manajemen Kurikulum Dalam Meningkatkan Mutu Pendidikan.” Tribakti Jurnal Pemikiran Kislaman 24, no. 1 (2013): 1-22. https://doi.org/https://doi.org/10.33367/tribakti.v24i1.126.

Lazwardi, Dedi. "Manajemen Kurikulum Sebagai Pengembangan Tujuan Pendidikan." Kependidikan Islam 7, no. 1 (2017): 99-112.

Luhanarky, Ayu. "Evaluasi Kurikulum 2013 Dalam Pembelajaran Matematika Permulaan di TK Negeri Pembina Cirebon." AWLADY: Jurnal Pendidikan Anak 5, no. 2 (2019): 16-33. https://doi.org/10.24235/awlady.v5i2.5128.

Mansur. Pendidikan Anak Usia Dini Dalam Islam. Yogyakarta: Pustaka Pelajar, 2005.

Muhammedi. "Peran Raudlatul Atfal (RA) Dalam Membina Generasi Islam Yang Berkarakter." Jurnal Raudhah 5, no. 1 (2017): 1-20. https://doi.org/DOI: http://dx.doi.org/10.30829/raudhah.v5i1.139.

Munajim, Ahmad, and Fikriyah. "Pengembangan Kurikulum Pembelajaran Di Masa Darurat." Jurnal Dwija Cendekia: Jurnal Riset Pedagogik 4, no. 2 (2020): 285-91. https://doi.org/https://doi.org/10.20961/jdc.v4i2.45288.

Munastiwi, Erni, and Marfuah Marfuah. "Islamic Education in Indonesia and Malaysia: Comparison of Islamic Education Learning Management Implementation." Jumal Pendidikan Islam 8, no. 1 (2019): 1-26. https://doi.org/10.14421/jpi.2019.81.1-26.

Pagarwati, Lia Dwi Ayu, and Arif Rohman. "Grandparenting Membentuk Karakter Anak Usia Dini Di Masa Pandemi Covid-19." Jurnal Obsesi : Journal of Early Childhood Education 5, no. 2 (2021): 1229-39. https://doi.org/10.31004/obsesi.v5i2.831.

Prasetia, Senata Adi, and Muhammad Fahmi. "Reorientasi, Peran Dan Tantangan Pendidikan Islamdi Tengah Pandemi." Jurnal Tarbawi STAI Al- Fitrah 9, no. 1 (2020): 21-35. https://doi.org/https://doi.org/10.36781/tarbawi.v9i1.3128.

Rachman, Fathor. "Managemen Organisasi Dalam Perspektif Al-Qur'an dan Hadist." Jurnal Studi Keislaman $1, \quad$ no. 2015$)$. http://ejournal.kopertais4.or.id/madura/index.php/ulumuna/article/view/1628/1202.

Rusman. Manajemen Kurikulum. Jakarta: PT Raja Grafindo Persada, 2009.

Salman, Ibnu, and Agus Widodo. "Kebijakan Peningkatan Mutu Pendidikan Raudlatul Atfal Dalam Telaah Restra Kemenag 2015-2019.” Modeling, Jurnal Program Studi PGMI 7, no. 2 (2020): 170. https://doi.org/doi: https://doi.org/10.36835/modeling.v7i2.664.

Satrianingrum, Arifah Prima, and Iis Prasetyo. "Persepsi Guru Dampak Pandemi Covid-19 Terhadap Pelaksanaan Pembelajaran Daring Di PAUD.” Jurnal Obsesi : Journal of Early 
Childhood Education 5, no. 1 (2021): 633-40. https://doi.org/10.31004/obsesi.v5i1.574.

Subhi, mam. "Urgensi Upaya Menjaga Mutu Pembelajaran Di Tengah Pndemi Covid 19." Edification Jurnal: Pendidikan Agama Islam 3, no. 1 (2020): 36-56. https://doi.org/doi: https://doi.org/10.37092/ej.v3i1.213.

Suhelayanti, and Ridwan Aziz. Manajemen Pendidikan. Edited by Toni Limbong. Pertama. Jakarta: Yayasan Kita Menulis, 2020.

Tim Dosen Adpen UPI. Manajemen Pendidikan. Bandung: Alfabeta, 2015.

Wahyudi, Nyoman Ary. "Kemendikbud Terbitkan Kurikulum Darurat, Ini Alasannya." Bisnis.com, 2020. https://kabar24.bisnis.com/read/20200807/15/1276481/kemendikbud-terbitkankurikulum-darurat-ini-alasannya.

Wardati, Laila, and Ade Khairunisa. "Pola Kerjasama Guru Dan Orang Tua Pada Masa Pandemi Covid 19 Di RA Masjid Agung Medan Polonia." Jurnal Pendidikan Islam Al Ulum 1, no. 2 (2020): 107-51. https://doi.org/10.30596/al-ulum.v.

Wilatikta, Ayu. "Manajemen Kurikulum Pendidikan Agama Islam Jenjang Pendidikan Dasar: Kontekstualisasi Strategi Pembelajaran Semasa Pandemi." Jurnal Ilmu Agama Islam 2, no. 2 (2020): 1-12. http://journal.uml.ac.id/TL/article/view/206. 